\title{
WALKING THE TALK? \\ An Examination of the Investments of Jesuit Universities in Fossil Fuel Firms
}

\author{
MARINILKA BARROS KIMBRO (corresponding author) \\ Albers School of Business \& Economics \\ Seattle University, Seattle, Washington, U.S.A \\ kimbrom@seattleu.edu \\ RUBINA MAHSUD \\ Albers School of Business \& Economics \\ Seattle University, Seattle, Washington, U.S.A \\ mahsudr@seattleu.edu
}

DAVIT ADUT

Albers School of Business \& Economics

Seattle University, Seattle, Washington, U.S.A

adutd@seattleu.edu

\begin{abstract}
This article investigates perspectives that have been proposed as reasons both for and against fossil fuel divestment (FFD), paying special attention to the decisions that universities make concerning investments in their endowment portfolios. Arguments that have been advanced against FFD include its supposedly lower financial returns, lack of direct control over investments, reliance on financial advisors, high transaction costs, the need for market index funds that include the stocks of fossil fuel firms, and the institution's fiduciary duty to increase returns. Arguments that have been advanced in favor of FFD include satisfactory returns from fossil fuel-free portfolios, risk reduction, the over-pricing of fossil fuel firms, improved portfolio diversification, and the need to align investing behavior with the institution's values, mission, and role in society.

The study challenges the alleged financial reasons for maintaining investments in fossil fuel firms by presenting evidence that divestment does not impair portfolio performance on a riskadjusted basis, nor does it increase long-term transaction costs. Fossil fuel firms are overvalued given that they will eventually suffer from the increasing demand for clean energy substitutes and face inevitable regulatory actions as the effects of climate change worsen. Divestment, therefore, might well provide higher risk-adjusted returns over the long-term.
\end{abstract}




\section{KEYWORDS}

divestment from fossil fuel firms; fossil fuel-free endowments; socially responsible investments in higher education; environmental justice and ethics

\section{BACKGROUND: EXPLORING THE QUESTION OF FOSSIL FUEL DIVESTMENT (FFD)}

The preceding paper in this issue of the Journal examined whether or not U.S.based Jesuit universities currently hold investments in fossil fuel firms in the context of their Jesuit identity and the pressures of student-led fossil fuel divestment (FFD) movements. It also briefly documented the impressive and inspiring efforts of student groups at Jesuit universities, such as Climate Justice at Boston College, ${ }^{1}$ Boston College Alumni for Divestment, Creighton University Climate Movement, Holy Cross Fossil Free, Fossil Free Fordham, Fossil Free Georgetown University, Fossil Free Gonzaga, Divest Gonzaga, Student Environmental Alliance at Loyola University Chicago, ECO Students Loyola Marymount University (LMU), Fossil Free LMU, Divest LMU, Fossil Free Loyola University New Orleans, Divest Loyola New Orleans, and Divest Santa Clara University, as well as the development of networks such as the Jesuit Divestment Network, Ignatian Solidarity Network, and Catholic Divestment Network, among others.

This present paper, in turn, briefly examines the effects of fossil fuels and carbon emissions on climate change, and describes the development of collective initiatives that urge these universities to remove or divest ("dis"-invest) from any financial holdings in firms that generate carbon emissions which contribute to global warming. The expectation that Jesuit universities would be more inclined to divest could also be construed as the logical response to Pope Francis's encyclical Laudato $\mathrm{Si}^{\prime}$ and to the increasing pressures exerted by student-led movements demanding FFD. Investigating how these institutions have responded to calls for FFD, therefore, is important and relevant in the context of their shared Roman Catholic identity, mission, and commitment to environmental sustainability. The good news is that

${ }^{1}$ In 2019, students voted for and approved a resolution demanding FFD. The Boston College Faculty Senate also approved a resolution in support of the same in April of that year. 
students are on board; anecdotal evidence strongly suggests that they are committed to and inspired by their faith, Roman Catholic/Jesuit identity, and Laudato Si'. Yet even though all 27 U.S.-based Jesuit universities "loudly" articulate their commitment to social justice and the protection of the environment, only two have committed to FFD: Seattle University and Georgetown. The remaining 25 have expressly rejected or ignored the loud calls for FFD; in other words, their investment policies do not align with their voiced environmental commitment. It begs the question, then, why they talk the talk but do not walk the walk. This paper, therefore, seeks to examine closely the reasons articulated by non-divesting U.S.-based Jesuit universities, and ultimately calls for a continuing dialogue on the question of divestment.

\section{Fossil Fuel Divestment in U.S.-based Jesuit Universities}

The Offices of the President, business school deans, and financial officers of U.S.-based Jesuit universities were contacted by email during the Spring and Summer of 2019 to verify data regarding their institutions' FFD status as well as request information about their investment policies regarding fossil fuel firms. ${ }^{2}$ Out of 13 respondents, ten also provided various degrees of information about the evaluation processes by which they decided to approve or reject FFD as well as reasons for doing so. Responses were obtained by email and telephone interviews, and while not all respondents requested confidentiality, attribution to any university was avoided to prevent breaches of confidentiality by way of elimination, particularly given the small number of respondents.

Non-divesting universities gave the following reasons for deciding against the elimination of fossil fuel holdings from their endowment portfolios: potentially lower financial returns of fossil fuel-free portfolios, their reliance on financial advisors and lack of direct control over investments, high transaction costs, the need for market index funds which include the stocks of fossil fuel firms, and their fiduciary duty to increase returns. Arguments in favor of divesting, on the other hand, included good-or even better-potential returns from fossil fuel-free portfolios, risk reduction, the overpricing of fossil fuel firms, and the alignment of investing behavior with institutional values, mission, and roles in society.

${ }^{2} \mathrm{~A}$ list of what are considered to be "fossil fuel firms" was also sent to all the universities (see Table 1 on page 55 of this issue of the Journal, which shows the Carbon Underground 200 list). 
In this paper, the financial arguments for and against divestment are presented in detail, followed by an attempt to discuss and evaluate them. This was done for two reasons. First, the interviews and data collection in the preceding paper as well as the literature on FFD focused almost primarily and exclusively on financial considerations. Thus, given that the arguments for and against FFD were overwhelmingly financial in nature, it was concluded that the main concern for universities is "Can we afford to divest?"

Second, there seemed to be little to no disagreement on the moral dimension of investing in and divesting from fossil fuel companies. There were no claims that FFD is inconsistent with the moral commitments of Jesuit universities, and neither was there evidence to suggest that these institutions might question the relationship between fossil fuels, carbon emissions, and climate change.

This article also does not discuss the responses of non-divesting universities and in the literature about whether or not divestment has any practical and/or significant impact, or how powerful any symbolic aspect of divestment actions might actually be. Nevertheless, it argues, in response to non-divesting universities claiming that divesting will not make a difference, for the importance of alignment in mission and actions, and that this (or its lack thereof) does send a message.

The reasons offered by non-divesting Jesuit universities for not divesting from fossil fuel firms are stated in more detail as follows:

1. Investments are made in index/mutual funds where $8 \%-11 \%$ of the holdings are typically exposed to fossil fuel firms (also referred to as commingled investment instruments). Officers from some of the universities that reported having two types of investmentsdirect and indirect (funds) — stated that while they avoid investing in fossil fuel firms in their direct investments (over which they have some control), indirect investments (over which they have no control) are typically index/mutual funds that have holdings in fossil fuel firms.

2. Divestment is perceived as incurring high transaction costs because it involves selling holdings and buying substitutes. 
3. Divestment is perceived as increasing portfolio risk.

4. Divestment is perceived as impairing diversification benefits like those provided by index/mutual funds.

5. Divestment is perceived as a political issue.

6. Divestment is framed by some universities as an either/or decision, and they prefer to express their commitment for environmental stewardships with more "visible" campus activities such as recycling, constructing green buildings, and implementing energy savings programs.

7. The boards of trustees of some universities perceive their "fiduciary responsibilities" in only monetary terms and feel that they are prevented from divesting because they believe it will result in lower returns and impair the financial position of the university.

8. Divestment is perceived as not likely to make a difference in carbon emissions.

9. Divestment is perceived to be a "contradictory message" since the university uses fossil fuels in other activities such as air conditioning, heating, etc.

\section{ARGUMENTS AND ADVOCACY AGAINST DIVESTMENT}

\section{Financial Returns: A Cost-Benefit Analysis}

In the discussion on whether or not to divest, the debate that usually arises is about the possible financial costs and benefits (returns) of divestments. Unless the economic implications of doing so are financially severe or even catastrophic, divesting from fossil fuels especially in faith-based universities seems like a decision where environmental values and social responsibility might well trump economic rationale, at least on the surface. Divesting from what is perceived as a profitable sector of the financial markets may also seem too risky a move for college and 
university endowments especially in an environment where competition for students is increasing and financial resources are stretched ever thinner.

There is, moreover, an abundance of oftentimes conflicting literature on the financial performance of socially responsible investments (SRI) (Renneboog, Ter Horst, \& Zhang, 2008). Some papers find that SRI funds do not earn statistically significant excess returns compared to conventional mutual funds (Hamilton, Jo, \& Statman, 1993); others claim that SRI funds underperform in many European and Asian markets (Renneboog et al., 2008; Fauver \& McDonald IV, 2014). Still other, more recent studies, on the other hand, find that SRI funds outperform traditional funds (Auer, 2016; Apfel, 2015).

Given that financial analysis plays a central role in divestment decisions, university decision-makers try to examine whether there will be a trade-off between a moral decision and the financial cost of that decision and, if so, what that cost might be. These questions, which almost every investor examines in one form or another, are often framed in terms of whether or not a portfolio will "lose" money, or, in a more proper context, whether or not limiting investment in certain companies will reduce financial returns in comparison to what they would have been otherwise. Weighing ethics against finances may be morally problematic, yet it is arguably a necessary question when trustees have, by law, a fiduciary responsibility to act entirely on the university's behalf and in its best interest.

There is a theoretical argument suggesting that divestment will result in lower returns, even though such was not brought forward by officers of the universities who were contacted for this study. It seems that most institutions believe that divesting will reduce their profits from their investments, that the logic against any divestment activity is that divestment itself leads to lower returns. If investors avoid fossil fuel firms, their doing so will decrease demand for the securities of these firms and create excess demand for the securities of non-fossil fuel firms, or so the reasoning goes. This shift in demand would thus reduce the stock prices of fossil fuel firms (underpricing those shares) and increase prices for (or overpricing) the non-fossil fuel stocks, thereby reducing the returns of fossil fuel-free portfolios as some of the portfolio holdings are shifted from high-yielding securities to loweryielding ones. ${ }^{3}$

'Investors would overpay for divestment and fossil fuel firms' portfolios would out-perform, resulting in positive alpha; divestment, on the other hand, would create negative alpha. 


\title{
Fiduciary Responsibility: The Role of Trustees
}

The dominance of certain financial norms can be interpreted as compelling managers of university endowments to make investment decisions in view only of the goal of maximizing the financial value of, and returns from, their portfolios. In examining the position of university boards of trustees, it is important to understand that they might believe, because of their perceptions of what their fiduciary responsibility might be, that they are legally unable to make any decision that might sacrifice financial returns even if it is for the benefit of the broader public or the planet. Since it is impossible to know the outcome of portfolio investments in advance, their decision-rationale must be based on what is legally referred to, according to fiduciary law, as what a "prudent person" would do in their situation (Waitzer \& Sarro, 2012). This implies that considerations of hypothetical returns are a major area of debate not only for financial but also for legal reasons. This question of financial ramifications remains, therefore, at the top of the priority list when it comes to fossil fuel divestment, as it was in past divestment campaigns. Beer (2016: 513) concludes, then, that there is evidence that investors who believe in SRI are willing to accept suboptimal financial performance to pursue social or ethical objectives. As quoted from a chair of a board's finance committee:

\begin{abstract}
The main driver was to align the actions of the college with the mission and the values of the college.... Maximizing returns in the endowment is an incomplete look at fiduciary duty. That duty can be trumped by other concerns. Human trafficking might also be highly profitable, but I think we would all agree that we would not want to own that stock. It is easy to overstate the case of fiduciary duty in seeking an excuse to avoid action such as divestment from fossil fuels. (Interview, May 23, 2014)
\end{abstract}

\section{Reliance on Financial Advisors and Market Index Funds}

Many universities outsource their investment functions or rely on financial advisors who recommend a conservative risk profile that tracks market indices. In these situations, choosing to divest from fossil fuel energy companies can be difficult given the composition of financial products and pooled funds whose asset holdings are dispersed across multiple sectors of the economy. Fossil fuel companies also make up an appreciable part of major benchmark indices since the energy sector represents a significant part of the equity markets. Fossil fuel firms engaged in "upstream" activities such as the exploration and production of fossil fuels, for instance, account for around 11\% of the S\&P 500 in the U.S. and 20\% of the FTSE 
100 in the United Kingdom. This presents a problem for chief financial officers who are unwilling, or feel unable, to recommend investments that are contrary to those proposed by their universities' financial advisors, especially when those very same advisors favor instruments that are embedded with fossil fuel firm securities (such as market index funds). This assertion, in fact, was confirmed by the individuals contacted for this study.

Relying heavily on financial advisors outside the university, therefore, might lead to inaction regardless of the personal positions of trustees and presidents. Indeed, one president argued as follows:

I think one of the issues is that traditionally, the committee of the board has run investment, and college presidents have been less engaged in those decisions and tended to leave it to the experts. We may not feel entirely comfortable to challenge [the investment experts'] assertions. They are the ones who work on Wall Street and we are just college presidents.

\section{Divestment and Diversification Risks}

Classical portfolio theory (Markowitz, 1952) suggests that constraining an investment portfolio will reduce opportunities for diversification which could thereby impair financial performance. The underlying rationale is that a greater set of alternatives increases the probability of better allocation for performance. ${ }^{4}$ Constraining financial holdings to non-fossil fuel firms, therefore, reduces the universe of opportunities for diversification which could potentially impair performance (Gasser, Rammerstorfer, \& Weinmayer, 2017).

\section{A NOTE ON ADVOCACY AGAINST DIVESTMENT}

There is evidence that anti-divestment groups have invested substantial resources in communicating that divestment will adversely affect investment returns. Organizations like the Independent Petroleum Association of America (IPAA), for instance, commissioned a study by Daniel Fischel, a professor of law and business at

${ }^{4}$ By constraining the investible universe, any divestment ends up imposing an inefficiency (cost) that increases diversifiable risk. The diversification cost that results from the divestment activity is the difference between the risk-adjusted returns of a fossil fuel-free portfolio and those of an unconstrained portfolio. This well-established theory assumes, of course, that all market participants (or at least a considerable majority) will participate in this disinvestment. 
the University of Chicago and chairman of the consulting group Compass Lexecon, to analyze the financial implications of divestment. The report, titled Fossil Fuel Divestment: A Costly and Ineffective Investment Strategy and which, apparently, did not undergo peer review, argues for the importance of fossil fuel company stocks in investment portfolios (Fischel, 2017). Using a limited sample period, Fishel's report concludes that divesting will result in portfolio losses (Apfel, 2015). Similarly, in a study also commissioned and financed by the IPAA and with the assistance of members of Compass Lexecon's professional staff, Cornell (2015) argues that owning the stocks of fossil fuel firms improves portfolio financial performance. It is worth noting, however, that these reports, as Trinks, Scholtens, Mulder, and Dam (2018) observe, use ad-hoc methods, limited firm samples, and study periods that might explain why they got such results.

\section{ARGUMENTS IN FAVOR OF DIVESTMENT: WHEN DIVESTMENT MAKES SENSE}

\section{Fossil Fuel-Free Portfolios Might Generate Equal or Higher Returns}

Research on the financial effects of fossil fuel divestment is sparse except for a few recent, comprehensive, and well-designed empirical studies. Henriques and Sadorsky (2018) found that fossil fuel divestment at statistically significant levels increased financial returns. Lewandowski (2017) discovered that companies with (relatively) lower carbon emissions have superior financial performance, implying that companies with high carbon emissions might be poor selections for inclusion in investment portfolios. Trinks et al. (2018) suggest that divestment portfolios are not negatively affected by the exclusion of fossil fuel stocks. Lastly, Hunt and Weber (2019) found that portfolios with lower carbon intensity had higher returns compared to the Canadian stock index for the period covering 2011-2015.

Geddes (2013) developed a model to back-test the impact that full divestment from fossil fuel firms would have on portfolio performance and found that annualized rolling returns would have been $0.1 \%$ to $0.2 \%$ higher than those from a Russell 3000 benchmark from 1997 through 2008. Morgan Stanley Capital International (MSCI, 2013) estimated, in similar fashion, that divesting the MSCI All Country World Investible Market Index (MSCI ACWI IMI) of fossil fuel assets over a period of five years (2008-2013) would have increased active returns by an average of $0.22 \%$ 
annually and overall tracking error by $1.9 \%$. More recent developments confirm this assertion-as of March 2020, the energy sector, which is composed of fossil fuel firms, had a TTM (Trailing Twelve Months) growth rate of negative $122.93 \%$ from the previous year's TTM. Even without the effects of the COVID-19 pandemic, the sector underperformed the market for nine years over the last decade (from 2010-2020). It was the market's worst performer every year-end up until and including 2019.

Fossil Fuel-Free Portfolios with "Green" Reallocation Might Generate Higher Returns

Hunt and Weber (2019) examined the effect of fossil fuel-free portfolios as well as divestment accompanied by re-investment in green industries in the Canadian Stock Index and found that divestment with green substitutes resulted in higher returns compared to the index fund benchmark. They also discovered that stricter divestment strategies in the carbon intensity of portfolios resulted in higher riskadjusted returns.

Fossil Fuel-Free Strategies Might Have No Impact On, or Even Reduce, Portfolio Risks

Geddes (2013) investigated portfolio volatility (after excluding coal firms with the highest carbon emissions) from 1997 to 2008 and found that divesting from fossil fuels can have minimal effect on a portfolio's performance and risk. In a comprehensive empirical study that compared the difference in portfolio risk and financial performance (returns) of investment portfolios with and without fossil fuel companies covering the period from 1927-2016 for all firms in the U.S. market, Trinks et al. (2018) discovered that divesting from the fossil fuel sector increased financial (risk-adjusted) returns compared to retaining unconstrained portfolios that included holdings in fossil fuel firms; in fact, they also concluded that the fossil fuel sector increases the risk of portfolios. In a similar vein, Morgan Stanley Capital International (MSCI, 2013) found that fossil fuel divestment has the potential, because of the volatility of the energy sector, to reduce overall risks in a portfolio.

\section{The "Carbon Bubble": The Over-Pricing of Fossil Fuel Firms}

"Carbon bubble" is a term mentioned by Leaton, Ranger, Ward, Sussams, and Brown (2013) and the Carbon Tracker Initiative that describes the "overvaluation" 
of fossil fuel reserves (assets) in fossil fuel firms. Such overvaluation stems from the probable emergence of competitive alternatives in renewables that would weaken demand for fossil fuels, an increased risk of future regulation, and the ultimate belief that a great amount of fossil fuel reserves will turn out to be unburnable (becoming "stranded assets") and worth far less, if anything, than alternative uses.

The "carbon bubble" exists not simply because those reserves are valued improperly but also because the true costs of carbon dioxide have not yet been considered. Fossil fuel companies are valued by the stock market in large part according to their reserves or amount of fossil fuels that they own and plan to extract. This, of course, is under the assumption that fossil fuel reserves will eventually be consumed and create revenue for the companies. However, only a limited amount of carbon and greenhouse gases can be emitted into the atmosphere before the planet becomes unlivable-probably the most common estimate indicates that a rise in average global temperature not exceeding $2{ }^{\circ} \mathrm{C}^{5}$ is the most that can be "tolerated" (IPCC, 2018). To cap the warming at that level, the burning of fossil fuels needs to be severely constrained, implying that most of the existing reserves should no longer be consumed. The amount of fossil fuels that can be burned to limit the warming to $2^{\circ} \mathrm{C}$ has thus been termed a "budget" that, if exceeded, would lead to extraordinary planetary warming. Leaton et al. (2013) estimate that a conservative carbon budget totaling 1,550 gigatons of equivalent carbon dioxide $\left(\mathrm{GtCO}_{2}\right)$ would be needed to achieve, with $50 \%$ probability, less than a $2^{\circ} \mathrm{C}$ increase in climate temperature; a carbon budget of $1,000 \mathrm{GtCO}_{2}$, on the other hand, would yield a $67 \%$ probability of avoiding the $2^{\circ} \mathrm{C}$ maximum. The budget to avoid an increase of $1.5^{\circ} \mathrm{C}$ is much less: $500 \mathrm{GtCO}_{2}$ for a $50 \%$ probability and only $416 \mathrm{GtCO}_{2}$ for a $67 \%$ probability.

The math is simple-the total fossil fuel reserves of listed firms as of July 2018 amounted to $521 \mathrm{GtCO}_{2}$, while state owned firms (that do not trade in the public markets) represented $75 \%{ }^{6}$ of total reserves worldwide; their reserves amounted to $2,084 \mathrm{GtCO}_{2}$. The amount of fossil fuel reserves worldwide as of July 2018, therefore,

${ }^{5} 2^{\circ} \mathrm{C}$ is equivalent to $3.6^{\circ} \mathrm{F}$.

${ }^{6}$ Nelson et al. (2014) estimate that most of the $\$ 25$ trillion in potentially stranded oil and gas assets would be on the books of various governments. National governments own $50 \%-70 \%$ of global fossil resources. 
totaled 2,605 $\mathrm{GtCO}_{2}$ (cf. Table 1 on page 55), yet we should not burn more than $1,550 \mathrm{GtCO}_{2}$ to avoid catastrophe. What happens to the rest, then?

In the worst-case scenario of a $2^{\circ} \mathrm{C}$ increase (and with only a $50 \%$ probability of not exceeding that), a capacity of $1,005 \mathrm{GtCO}_{2}$ of fossil fuels, of which 264 $\mathrm{GtCO}_{2}$ would belong to the reserves of listed fossil fuel firms, would remain unburnable. The more probable (67\%) scenario would leave behind 1,650 $\mathrm{GtCO}_{2}$ of unusable (stranded) fossil fuels, of which $413 \mathrm{GtCO}_{2}$ would belong to listed firms. Lewis (2014) thus projects that policies and technologies consistent with the $2{ }^{\circ} \mathrm{C}$ threshold would put $\$ 28$ trillion of fossil energy company revenues at risk. ${ }^{7}$ Table 1 below shows the impossibility of burning all the fossil fuel assets currently available as disclosed by fossil fuel firms.

\begin{tabular}{|c|c|}
\hline \multicolumn{2}{|c|}{ TO AVOID A $2^{\circ} \mathrm{C}$ INCREASE IN TEMPERATURE BY 2030* } \\
\hline Probability of staying below $2^{\circ} \mathrm{C}$ & Maximum amount of $\mathrm{GtCO}_{2}{ }^{* *}$ \\
\hline $50 \%$ & 1,222 to 1,550 \\
\hline $67 \%$ & 880 to 1,000 \\
\hline \multicolumn{2}{|c|}{ TO AVOID A $1.5^{\circ} \mathrm{C}$ INCREASE IN TEMPERATURE BY $2030^{*}$} \\
\hline Probability of staying below $1.5^{\circ} \mathrm{C}$ & Maximum amount of $\mathrm{GtCO}_{2}$ \\
\hline $50 \%$ & 500 \\
\hline $67 \%$ & 416 \\
\hline \multicolumn{2}{|c|}{ FOSSIL FUEL RESERVES (GtCO ${ }_{2}$ ) (AS OF JULY 2018) } \\
\hline Listed firms & 521 \\
\hline Non-listed government owned firms & 2,084 \\
\hline Total Fossil Fuel Reserves & 2,605 \\
\hline
\end{tabular}

Table 1: $\mathrm{GtCO}_{2}$ Budget \& Fossil Fuel Reserves

(IPCC, 2018; see also Schurer, Mann, Hawkins, Tett, \& Hegerl, 2017)

${ }^{*}$ Increase in temperature above pre-industrial levels (1850-1900)

${ }^{* \star}$ See IEA, 2017

The math and logic illustrated in Table 1 above leave us with two possible scenarios: either some of these fossil fuel reserves are left in the ground to avoid catastrophe (they become stranded assets), or they are used and burned at their presumed market value, causing runaway global warming and very likely leading to an unlivable planet.

${ }^{7}$ McGlade \& Ekins (2015) project that $30 \%$ of oil, $50 \%$ of gas, and $80 \%$ of coal reserves will become stranded assets. 
The business model of companies that plan to extract these fossil fuels will suffer, therefore, if action on climate is taken, and when market players finally realize that some of these assets (reserves) are worthless since these fuels need to be left in the ground for the survival of most living species and, ultimately, for life as we know it. It is virtually impossible, in other words, to burn all the stated fossil fuel reserves without creating an unlivable planet.

If we assume that action will be taken to reduce $\mathrm{CO}_{2}$ emissions, the value of these reserves will be adjusted. Investor portfolios with exposure to the stocks of fossil fuel companies will suffer as the market realigns, and/or when the "bubble" bursts, creating huge losses. Infrastructure tied up in the refining and delivery of fossil fuels will also be at risk financially. These reserves and infrastructure will become "stranded assets," or assets that cannot be used or extracted and therefore have no value for investors.

If an investor believes, therefore, that society will react in some way to climate change, he/she should take a financial position to prepare for that scenario; in investment terminology, this can be called a "bet" that fossil fuels will be kept in the ground. It is very plausible, in fact, to advocate for divestment based on a prediction of strong declines in the stock prices of fossil fuel companies. Leaton (2011), Battiston, Mandel, Monasterolo, Schütze, and Visentin (2017), and Dietz, Bowen, Dixon, and Gradwell (2016) find that the financial implications of various climate policy scenarios will result in material negative valuation impacts for fossil fuel firms. Indeed, various studies find that divesting might be a way to avoid financial losses resulting from the potential burst of the carbon bubble due to stranded assets (Ansar, Caldecott, \& Tilbury, 2013; Beer, 2016). This hypothesis is supported by Henriques and Sadorsky (2018) who find that divesting from fossil fuel companies and replacing these positions with clean energy firms already increases financial returns because of the higher performance of clean energy stocks.

The scenarios above, moreover, do not account for improvements in renewables and efficiency technologies which would undermine the long-term demand for fossil fuel energy and suggest a past peak demand environment for oil, gas, and coal. Two major trends support this possibility: 1) an increase in the supply of crude and natural gas production brought about by better extraction technologies and 2) limits on net export availability in major exporting nations as their own population growth 
requires increasing consumption. If these trends continue, sustaining the economic case for fossil fuel dependency will become a more painful option compared to restructuring the economy around alternative energy sources.

\section{Portfolio Diversification: Risks and Benefits}

Trinks et al. (2018) examined returns for the period 1927-2016 and found no difference in $\beta$ (beta) between the fossil fuel industry and the rest of the market, implying that fossil fuel stocks are a substitute for the market index and provide limited risk diversification benefits. On the other hand, they found no significant reduction in diversification benefits following fossil fuel divestment; in fact, the high $\alpha$ (alpha or undiversifiable risk) of fossil fuel firms confirms that they add risk to any portfolio. Trinks et al. (2018), for instance, found that the coal sector significantly underperforms compared to coal-free portfolios that outperform them consistently. Divestment, therefore, would effectively reduce (or at least not affect) diversification risk while benefiting from the advantages of market index investing.

Following this risk diversification strategy, the University of California system eventually agreed to divest fully from fossil fuel investments. As per their chief investment officer, "We believe hanging on to fossil fuel assets is a financial risk. That's why we will have made our \$13.4-billion endowment 'fossil free' as of the end of this month, and why our \$70-billion pension will soon be that way as well" (Bachher \& Sherman, 2019).

\section{CONCLUSION}

There is no doubt that climate change is the greatest challenge our generation and species has ever faced. We know this. University presidents know this. Nearly everything we know about climate change and global warming today was known in 1988, when Hansen testified to Congress, and even before then. The "greenhouse effect" is not that complicated-the more $\mathrm{CO}_{2}$ in the atmosphere, the warmer the planet-and yet more carbon has been released since 1989 than in the entire history of civilization before then. The world has warmed by $1^{\circ} \mathrm{C}$ since the Industrial Revolution, and it will warm by another $0.5^{\circ} \mathrm{C}$ within the next 12 years. The "best case scenario" would be to limit the increase to $2^{\circ} \mathrm{C}$ which would result in the destruction of tropical reefs, a sea level rise of several meters, the extinction of 
most living species, and mass migrations that will exacerbate regional conflicts and battles over natural resources. A $3^{\circ} \mathrm{C}$ warming would imply the abandonment of coastal cities, forests growing in the arctic, massive droughts, and mass starvation. If fossil fuels continue to burn at the current rate, our future will be far less livable than our present.

The rejection of reason opens the door to the rejection of morality, for morality relies on faith in reason. We do not hesitate to summon morality in debates about racial injustice, immigration, gun violence, nuclear proliferation, or even tobacco marketing campaigns. Discussions of climate change, however, remain framed within political, economic, financial, and legal considerations. Yet climate change is a moral issue, and fighting to reduce fossil fuel emissions is a struggle for survival. How, then, can we live with inaction? The alternative is to keep financing the fossil fuel industry and wait for the suffering to become unbearable, to pursue the status quo for 10-12 years, the time left to reach a warming of $1.5^{\circ} \mathrm{C}$ and witness the multiplying tragedies of a warming world.

The values embedded in the mission of a college or university serve as guideposts on the route to making decisions. Even clearer, however, is that the morality in a mission serves as material to justify policies that prioritize ecological sustainability over purely financial gain, despite the cultural dominance of market values in the broader society.

The divestment agenda is worth pushing. It offers some distinct advantages over other kinds of efforts, provides a clear-cut moral message, and makes a statement with money. Divestment is a powerful strategy, one that can, in the right context and with proper consideration, be used to raise public awareness, influence policy, and, in some situations, influence corporate behavior. The effect of the divestment movement goes beyond a single congregation or university-it provokes reflection in churches and debates on campuses and in family dining rooms which inevitably spill over to corporate boards, city councils, and national policy circles. Debates around specific investments also inevitably create a local platform for the discussion of global issues, helping change public opinion and allowing organizations and communities to demonstrate their concerns. The "fossil-free campaign" has the potential, therefore, of stimulating grassroots 
debates about the issue of climate change, an issue which, unfortunately, too often seems abstract and intractable.

At the end of the day, actions will of course speak for themselves. Yet even if institutions refuse to divest, it is hoped that this paper will inspire discussions that raise awareness of, and draw attention to, an existential issue that can prompt reflection on our faith, values, and moral stance. As students involved in the fossil fuel-free movement have come to realize over time, debates over divestment can push broader communities to think more carefully, and perhaps more critically, about whether and when moral concerns should override market forces. There is no question that a powerful message will be sent if enough institutions divest from fossil fuel holdings. Doing so will be a symbolic push for change, one with the potential of shifting policy that will eventually support the transition to a fossil fuel-free economy.

It is perhaps most ironic of all that the arguments for not divesting from fossil fuels are overwhelmingly, and often exclusively, couched in financial terms: "we cannot afford to act morally." This financial reasoning is weak, and there is no compelling evidence that divesting will hurt returns; in fact, it appears at least as likely, or perhaps even a bit more so, that divesting will protect and maybe even enhance them. Acting in ways consistent with our values and moral beliefs, it turns out, might be the "most profitable thing to do."

The game has changed. The challenge is no longer for university officers responsible for investing endowment portfolios to say to students, faculty, and alumni that "we cannot invest our funds in ways consistent with our values and mission until you prove to us that doing so will not harm the university's financial returns." The new challenge arises from students, faculty, and alumni who say to those officers,

\footnotetext{
Please prove to us that we cannot afford to invest our endowment funds in ways consistent with our values and moral beliefs. Prove to us that we cannot act morally ... and, oh yes, in fairness to you, let us warn you that even if you can convince us that there is a cost to acting morally, we might say: "Thank you, let's act morally anyway. We are a university after all, not Gordon Gekko."8
}

${ }^{8}$ Gordon Gekko is a fictional character in the movie Wall Street and its sequel Wall Street: Money Never Sleeps. He is known for the quote "Greed, in all of its forms, greed for life, for money, 


\section{REFERENCES}

Ansar, A., Caldecott, B., \& Tilbury, J. 2013. Stranded assets and the fossil fuel divestment campaign: What does divestment mean for the valuation of fossil fuel assets? Stranded Assets Programme, Smith School of Enterprise and the Environment, University of Oxford. Available at https://www.smithschool. ox.ac.uk/publications/reports/SAP-divestment-report-final.pdf (accessed May 19, 2019).

Apfel, D. 2015. Exploring divestment as a strategy for change: An evaluation of the history, success, and challenges of fossil fuel divestment. Social Research, 82(4): 913-937.

Auer, B. R. 2016. Do socially responsible investment policies add or destroy European stock portfolio value? Journal of Business Ethics, 135(2): 381-397.

Bachher, S., \& Sherman, R. 2019. Opinion: UC investments are going fossil free. But not exactly for the reasons you may think. Los Angeles Times, September 17.

Battiston, S., Mandel, A., Monasterolo, I., Schütze, F., \& Visentin, G. 2017. A climate stress-test of the financial system. Nature Climate Change, 7(4): 283-288.

Beer, C. T. 2016. Rationale of early adopters of fossil fuel divestment. International Journal of Sustainability in Higher Education, 17(4): 506-519.

Cornell, B. 2015. The divestment penalty: Estimating the costs of fossil fuel divestment to select university endowments. Divestment Facts. Available at http://divestmentfacts.com/wp-content/uploads/2015/09/THE-DIVESTMENTPENALTY.pdf (accessed May 12, 2019).

Dietz, S., Bowen, A., Dixon, C., \& Gradwell, P. 2016. "Climate value at risk" of global financial assets. Nature Climate Change, 6(7): 676-679.

Fauver, L., \& McDonald IV, M. B. 2014. International variation in sin stocks and its effects on equity valuation. Journal of Corporate Finance, 25: 173-187.

for love, knowledge, has marked the upward surge in mankind" (https://www.inspiringimages. org/2019/11/gekko-inspirational-images-quotes-from.html). 
Fischel, D. R. 2017. Fossil fuel divestment: A costly and ineffective investment strategy. Divestment Facts. Available at http://divestmentfacts.com/pdf/Fischel_ Report.pdf (accessed June 11, 2019).

Gasser, S. M., Rammerstorfer, M., \& Weinmayer, K. 2017. Markowitz revisited: Social portfolio engineering. European Journal of Operational Research, 258(3): 1181-1190.

Geddes, P. 2013. Do the investment math: Building a carbon-free portfolio. Sausalito, CA: Aperio Group.

Hamilton, S., Jo, H., \& Statman, M. 1993. Doing well while doing good? The investment performance of socially responsible mutual funds. Financial Analysts Journal, 49(6): 62-66.

Henriques, I., \& Sadorsky, P. 2018. Investor implications of divesting from fossil fuels. Global Finance Journal, 38: 30-44.

Hunt, C., \& Weber, O. 2019. Fossil fuel divestment strategies: Financial and carbonrelated consequences. Organization \& Environment, 32(1): 41-61.

IEA [International Energy Agency]. 2017. World energy outlook 2017. Paris. Available at https://www.iea.org/reports/world-energy-outlook-2017.

IPCC [Intergovernmental Panel on Climate Change]. 2018. Summary for policymakers. In V. Masson-Delmotte, P. Zhai, H.-O. Pörtner, D. Roberts, J. Skea, P. R. Shukla, A. Pirani, W. Moufouma-Okia, C. Péan, R. Pidcock, S. Connors, J. B. R. Matthews, Y. Chen, X. Zhou, M. I. Gomis, E. Lonnoy, T. Maycock, M. Tignor, $\&$ T. Waterfield (Eds.), Global warming of $1.5^{\circ} \mathrm{C}$ : An IPCC special report on the impacts of global warming of $1.5^{\circ} \mathrm{C}$ above pre-industrial levels and related global greenhouse gas emission pathways, in the context of strengthening the global response to the threat of climate change, sustainable development, and efforts to eradicate poverty: 1-24. World Meteorological Organization, United Nations. 
Leaton, J. 2011. Unburnable carbon-Are the world's financial markets carrying a carbon bubble? London, UK: Carbon Tracker Initiative. Available at https://www. banktrack.org/download/unburnable_carbon/unburnablecarbonfullrev2.pdf.

Leaton, J., Ranger, N., Ward, B., Sussams, L., \& Brown, M. 2013. Unburnable carbon 2013: Wasted capital and stranded assets. London, UK: Carbon Tracker Initiative \& Grantham Research Institute on Climate Change and the Environment.

Lewandowski, S. 2017. Corporate carbon and financial performance: The role of emission reductions. Business Strategy and the Environment, 26(8): 1196-1211.

Lewis, M. C. 2014. Stranded assets, fossilised revenues. Kepler Cheuvreux ESG Sustainability Research, April 24: 1- 35.

Markowitz, H. 1952. Portfolio selection. Journal of Finance, 7(1): 77-91.

McGlade, C., \& Ekins, P. 2015. The geographical distribution of fossil fuels unused when limiting global warming to $2^{\circ} \mathrm{C}$. Nature, 517(7533): 187-190.

MSCI [Morgan Stanley Capital International]. 2013. Responding to the call for fossilfuel free portfolios. MSCI ESG Research Issue Brief, December.

Nelson, D., Hervé-Mignucci, M., Goggins, A., Szambelan, S. J., Vladeck, T., \& Zuckerman, J. 2014. Moving to a low-carbon economy: The impact of policy pathways on fossil fuel asset values. Climate Policy Initiative. Available at https://climatepolicyinitiative.org/wp-content/uploads/2014/10/Moving-to-aLow-Carbon-Economy-The-Impacts-of-Policy-Pathways-on-Fossil-Fuel-AssetValues.pdf.

Renneboog, L., Ter Horst, J., \& Zhang, C. 2008. Socially responsible investments: Institutional aspects, performance, and investor behavior. Journal of Banking \& Finance, 32(9): 1723-1742.

Schurer, A. P., Mann, M. E., Hawkins, E., Tett, S. F., \& Hegerl, G. C. 2017. Importance of the pre-industrial baseline for likelihood of exceeding Paris goals. Nature Climate Change, 7(8): 563-567. 
Trinks, A., Scholtens, B., Mulder, M., \& Dam, L. 2018. Fossil fuel divestment and portfolio performance. Ecological Economics, 146: 740-748.

Waitzer, E. J., \& Sarro, D. 2012. The public fiduciary: Emerging themes in Canadian fiduciary law for pension trustees. Canadian Bar Review, 91: 163-209.

Marinilka Barros Kimbro is an Associate Professor of Accounting at the Albers School of Business and Economics, Seattle University. She received a Ph.D. in Accounting from the University of Maryland, College Park and has held research appointments at the University of Washington, Groupe HEC-Paris, Hong Kong Polytechnic, IE-Madrid, and Gonzaga University. Her scholarship examines the role of information in firm risk, shareholders' activism, executive compensation, and decision making. Her publications appear in the Journal of Accounting and Public Policy, Journal of Accounting, Auditing \& Finance, Asia-Pacific Journal of Accounting \& Economics, and Journal of International Financial Management \& Accounting, among others. Her research attempts to generate "engaged scholarship" that is relevant to her teaching, to the profession, and that expresses Seattle University's mission of social justice.

Rubina Mahsud is a thought leader in business education, corporate strategy, and leadership whose work spans from humanitarian services to return on shareholder equity. Her articles have appeared in the Journal of Managerial Psychology, Journal of Leadership and Organizational Studies, Personnel Review, and Business and Society Review. She currently serves as an Associate Professor of Management at the Center for Leadership Formation, Albers School of Business \& Economics at Seattle University. Dr. Mahsud holds her Ph.D. in Management as well as a master's degree in Public Health from the State University of New York at Albany. Her prior degrees include a master's in Social Sciences from the University of Birmingham (U.K.) and a medical degree from Jinnah Medical College (Pakistan).

Davit Adut, Ph.D., is an Assistant Professor of Accounting at the Albers School of Business and Economics, Seattle University whose research focuses on the effect of accounting information on executive compensation, analysts' forecasts, and corporate governance. He has held research appointments at the American University and University of Cincinnati, and his publications appear in Accounting Review, Journal of Accounting and Public Policy, and Advances in Accounting. Dr. Adut also serves as the senior editor for International Accounting, Auditing, and Taxation. 